\title{
DEKONSTRUKSI CERITA RAKYAT INDONESIA DALAM IKLAN TELEVISI
}

\section{DECONSTRUCTION OF FOLK'S STORIES IN TELEVISION ADVERTISEMENT}

\author{
Gunawan Wiradharma ${ }^{1}$, Khusnul Fatonah ${ }^{2}$, Dede Mahmudah ${ }^{3 * *}$ \\ ${ }^{1}$ Universitas Terbuka \\ Jalan Cabe Raya, Tangerang Selatan, Indonesia \\ ${ }^{2}$ Universitas Esa Unggul \\ Jalan Arjuna Utara, Jakarta Barat, Indonesia \\ ${ }^{3}$ BPSDMP Kominfo Jakarta, Kementerian Komunikasi dan Informatika \\ Jalan Pegangsaan Timur, Jakarta Pusat, Indonesia \\ ' gunawan.wiradharma@ecampus.ut.ac.id; ${ }^{2}$ khusnul.fatonah@esaunggul.ac.id; ${ }^{3}$ dede002@kominfo.go.id \\ Diterima tgl. 19/07/2020 Direvisi tgl. 21/10/2020 Disetujui tgl. 06/11/2020
}

\begin{abstract}
The challenge to maintain the sustainability of Indonesian folklore is big that it may cause the loss of pride in Indonesian folklore among the youth. One of the efforts made by PT Lasallefood Indonesia is by presenting a Marjan syrup advertisement themed Indonesian folklore in Ramadhan. This study describes how Indonesian folklore, a traditional cultural product, is deconstructed into a syrup product television advertising with its creative side in generating brand awareness to the audience. This is a qualitative research relying on Derrida's Deconstruction theory. The data in this study are the folklore of Timun Mas and Lutung Kasarung. The result is the deconstruction of the folklore in Marjan's advertisement is not entirely the same as the original story. The folklore presented has almost all been developed. Some have been reconstructed into advertisements with a new and modern storyline, even though the characters presented are still the same. Some characterizations have changed, but don't affect the essence of the story. The folklore story plot has all been almost developed. The brand is featured three times at every important and reasonable moment. This advertisement has made a breakthrough to introduce Indonesian folklore that is full of moral messages with a contemporary look.
\end{abstract}

Keywords: Deconstruction, Folklore, Television Commercials, Marjan Syrup

\begin{abstract}
ABSTRAK
Tantangan untuk mempertahankan kelestarian cerita rakyat Indonesia semakin besar dengan banyaknya budaya global yang masuk ke Indonesia sehingga tidak menutup kemungkinan hilangnya rasa kebanggan terhadap cerita rakyat Indonesia di kalangan generasi muda. Salah satu upaya telah dilakukan oleh PT Lasallefood Indonesia dengan menghadirkan iklan sirop Marjan yang bertemakan cerita rakyat Indonesia menjelang dan hingga akhir Ramadhan. Penelitian ini bertujuan untuk mendeskripsikan bagaimana cerita rakyat Indonesia sebagai produk budaya tradisional didekonstruksi menjadi iklan televisi produk sirop serta melihat sisi kreativitasnya dalam memunculkan brand awareness kepada penonton. Metode yang digunakan dalam penelitian ini ialah metode kualitatif yang ditopang oleh teori dekonstruksi Derrida. Data dalam penelitian ini adalah cerita rakyat Timun Mas dan Lutung Kasarung. Hasil penelitian menjelaskan bahwa cerita rakyat yang ada dalam iklan Marjan mengalami dekonstruksi dan tidak sepenuhnya sama dengan cerita aslinya. Penokohan dan perwatakan ada yang mengalami perubahan, tetapi tidak memengaruhi esensi cerita. Alur cerita rakyat yang ditampilkan dalam iklan Marjan hampir semuanya telah dikembangkan. Brand sirop Marjan juga ditampilkan sebanyak tiga kali pada setiap momen penting dan masuk akal. Iklan ini telah melakukan terobosan untuk memperkenalkan cerita rakyat Indonesia yang sarat dengan pesan moral dengan tampilan kekinian.
\end{abstract}

Kata Kunci: Dekonstruksi, Cerita Rakyat, Iklan Televisi, Sirop Marjan

\footnotetext{
** Semua penulis merupakan kontributor utama
} 


\section{PENDAHULUAN}

Indonesia kaya akan cerita-cerita rakyatnya. Dari Sabang sampai Merauke, beragam cerita rakyat tersebar dalam berbagai versi, lengkap dengan keunikan, atau ciri khas daerahnya masingmasing. Cerita rakyat merupakan cerita yang berasal dari suatu masyarakat di daerah tertentu dan berkembang di masyarakat tersebut. Bentuknya pun ada yang berupa legenda, mitos, atau dongeng (Danandjaja, 2007). Pada mulanya, cerita ini dituturkan secara lisan dan turun-temurun. Pengarangnya pun anonim alias tidak diketahui.

Upaya untuk mempertahankan kelestarian cerita rakyat Indonesia penuh tantangan. Era globalisasi telah memunculkan banyak kebudayaan modern yang lebih menarik perhatian para generasi muda. Jika tidak bisa dikendalikan dengan baik, hal-hal tersebut akan memberikan dampak negatif, yakni adanya pergeseran budaya di kalangan generasi muda saat ini.

Peneliti kebudayaan dari Balai Pelestarian Nilai Budaya Bandung, Ani Rostiyati, dalam wawancaranya dengan ayobandung.com (2017) menuturkan bahwa pergeseran budaya terhadap generasi muda telah terjadi saat ini. Mereka lebih banyak tahu tentang game, film, dan lebih banyak menyukai budaya luar, misalnya budaya Korea. Belum lagi adanya internet yang memudahkan mereka untuk mengakses semua itu. Namun, ketika ditanya tentang cerita rakyat yang berasal dari daerahnya masing-masing, tak sedikit yang menjawab tidak tahu. Dengan kata lain, cerita rakyat kalah populer dengan cerita-cerita lain yang lebih modern. Hal senada juga disampaikan (Latif C.M., 2019) dalam penelitiannya yang menjelaskan bahwa mahasiswa Indonesia lebih fasih dan sangat loyal dengan konten yang berbau luar (Latif C.M., 2019). Alhasil, pengetahuan mereka tentang konten lokal sangat terbatas. Anak-anak sekarang juga lebih hafal kisah "Dargon Ball" daripada "Jaka Tingkir" yang melegenda. Pun dengan cerita anak HC Anderson yang lebih populer dan berkelas daripada cerita Kleting Kuning. Padahal, beberapa puluh tahun yang lalu, cerita rakyat sangat akrab dengan masyarakat Indonesia, khususnya anak-anak. Masalah yang sama juga disampaikan Mujtaba dan Hartati (2019) tentang kegelisahannya terhadap folklor lisan, khususnya folklor berbasis pertunjukan yang terancam punah. Salah satu upaya yang dilakukan adalah dengan memberikan kontribusi akademik terhadap seni yang mengangkat budaya lokal. Pengkajian secara ilmiah berkaitan dengan pelestarian cerita rakyat menjadi penting untuk menjawab berbagai permasalahan tersebut (Hartati, 2019).

Masalah-masalah tersebut tentu menjadi hal penting untuk dikaji kembali. Perkembangan teknologi saat ini seyogyanya dapat dimanfaatkan untuk melestarikan beragam kekayaan bangsa Indonesia, termasuk cerita rakyat. Tak dapat dipungkiri bahwa cerita rakyat merupakan salah satu kekayaan bangsa Indonesia peninggalan nenek moyang sejak ratusan tahun yang lalu dan sarat dengan nilai-nilai luhur bangsa Indonesia yang perlu diteruskan ke generasi selanjutnya. Gap analysis dalam penelitian ini berkaitan dengan adanya pengaruh globalisasi yang memunculkan banyak kebudayaan modern. Salah satu upaya yang dapat dilakukan untuk mengatasi "gempuran" tersebut adalah dengan menampilkan kembali salah satu bentuk kekayaan Indonesia, misalnya cerita rakyat dalam sebuah iklan. Tentunya alur cerita yang dikembangkan disesuaikan dengan kondisi saat ini dan lebih modern atau kekinian.

Penggunaan beragam media untuk memperkenalkan kembali cerita rakyat sebenarnya sudah dilakukan, baik dalam bentuk cerita bergambar (Ruslan, 2016), foto berkisah (Latif C.M., 2019), anime (Damayanti, 2018), video animasi (Setyawan, 2013), aplikasi berbasis mobile (Yusa, 2014), dan channel Youtube Dongeng Kita yang khusus menyajikan cerita rakyat Indonesia. Bahkan, belum lama ini, pengenalan tentang cerita rakyat Indonesia juga disampaikan melalui iklan televisi. Iklan sebagai salah satu bentuk komunikasi massa dapat pula dijadikan sebagai potret realitas yang ada di masyarakat. Selain, sebagai sarana promosi untuk menawarkan barang dan jasa, iklan juga 
mengalami perluasan fungsi sebagai alat untuk menanamkan makna simbolik melalui bahasa dan visualisasi dalam pesan-pesannya (Vera, 2014). Memindahkan sesuatu dari satu tempat ke tempat lain, dalam hal ini cerita rakyat yang dituturkan secara lisan menjadi bentuk cerita bergambar, foto berkisah, anime, video animasi, bahkan iklan disebut sebagai alih wahana. Bentuk yang dipindahkan tersebut dapat berupa gagasan, amanat, perasaan, atau sekadar suasana (Damono, 2018). Jika didasarkan pada konsep Eneste dapat dipetakan bahwa perubahan yang terjadi meliputi penambahan, pengubahan bervariasi, dan pengurangan (Suseno, 2019). Dengan demikian, alih wahana membawa perubahan yang siginifikan karena adanya perubahan medium/media yang digunakan dengan konsep atau tampilan yang lebih kekinian. Bahkan, alih wahana dapat dijadikan sebagai salah satu media pelestarian berbagai karya (Damayanti, 2018).

Kemenarikan (attention) sebuah iklan agar bisa diterima konsumen bukanlah hal yang mudah. Selain kreatif, iklan yang disajikan juga harus unik dan berani tampil "beda" dari iklan-iklan yang sudah ada. Kriteria lain yang perlu diperhatikan dalam mengiklankan sebuah produk adalah mengandung perhatian dan minat (interest), memunculkan keinginan pembeli untuk mencoba atau memiliki (desire), menimbulkan keyakinan terhadap produk (conviction), menghasilkan kepuasan terhadap produk (decision), dan mengarah pada tindakan untuk membeli (action) (Lukitaningsih, 2013). Untuk mencapai semua itu, dibutuhkan strategi kreatif iklan agar pesan tersebut dapat tersampaikan langsung ke target yang dituju dan mampu memikat khalayak ramai (Oktafiandi, 2018). Sebagai contoh, pada tahun 2017 PT Indolakto (Indofood Group) meluncurkan kembali salah satu produk andalannya, yakni Indoeskrim yang merupakan produk es krim lokal. Iklan tersebut berlatar zaman kerajaan dan dikemas dalam bentuk film kolosal Brama Kumbara yang dimodernisasi. Tak disangka, ternyata iklan tersebut sukses menarik perhatian penonton dan menjadi salah satu Youtube's Top 10 Ads Leaderboard Award (Oktafiandi, 2018).

Jauh sebelum kemunculan iklan Indoeskrim dengan konsep Nusantara ini hadir, pada tahun 2010, PT Lasallefood Indonesia ternyata lebih dulu mengiklankan salah satu produk andalannya, yakni Sirop Marjan dengan mengusung tema keragaman budaya Indonesia. Iklan yang secara konsisten hadir untuk menyambut bulan Ramadhan ini dikemas dalam bentuk cerita bersambung. Konsep iklan bersambung ini digunakan Marjan sebagai upaya untuk meningkatkan daya tarik masyarakat. Hal ini penting karena akan berpengaruh pada tingkat keberhasilan komunikasi kepada khalayak (Handayani, 2019). Keunikan lainnya adalah Marjan juga menampilkan cerita rakyat dalam iklannya. Kedua cerita rakyat tersebut diperkenalkan kembali dengan versi yang lebih modern agar bisa diterima oleh generasi muda saat ini. Berbicara tentang cerita rakyat dalam iklan, sebelumnya melakukan penelitian serupa dengan fokus kajian pada konstruksi cerita rakyat (folklore) Jepang dalam iklan televisi produk Smartphone AU (Aminova, 2017). Hal ini membuktikan bahwa penelitian tentang cerita rakyat masih menarik dan penting untuk dikaji.

Sesuai dengan latar belakang yang dijelaskan, rumusan masalah dalam penelitian ini berkaitan dengan dekonstruksi cerita rakyat dalam iklan televisi. Dengan menggunakan teori Dekonstruksi Derrida, penelitian ini memberikan kesempatan untuk memberdayakan makna-makna yang tersirat yang sengaja disembunyikan atau dilupakan karena adanya prioritas tertentu dalam teks tersebut. Derrida beranggapan bahwa tidak ada pemaknaan tunggal dalam sebuah teks sehingga sifat tersebut menjadi ambigu akibat munculnya pemaknaan-pemaknaan baru (Syafrina, 2014). Penelitian ini bertujuan untuk mendeskripsikan bagaimana cerita rakyat Indonesia yang merupakan produk budaya tradisional didekonstruksi menjadi iklan sirop untuk melihat sisi kreativitas iklan Marjan dalam memunculkan brand awareness pada penonton.

Hasil penelitian ini dapat dimanfaatkan oleh berbagai pihak, baik itu pendidik, content creator, orang tua, atau masyarakat pada umumnya. Bagi seorang pendidik, iklan Marjan dengan tema cerita rakyat dapat dijadikan bahan atau media pembelajaran cerita rakyat di kelas. Bagi content 
creator, mereka dapat menggunakan cerita rakyat Indonesia sebagai ide dalam pembuatan iklannya. Selain mendapatkan keuntungan komersial, secara tidak langsung mereka juga turut serta memperkenalkan cerita rakyat secara luas melalui media televisi. Hal ini yang juga menjadi perhatian orang tua dan masyarakat untuk terus melestarikan cerita rakyat kepada anak-anaknya agar kelak mereka mampu menjaga salah satu kekayaan bangsa Indonesia.

\subsection{Teori Dekonstruksi Derrida}

Dekonstruksi yang dipelopori oleh Jacques Derrida hadir untuk memberikan kritik terhadap strukturalisme. Selain itu, dekonstruksi juga hadir untuk menolak adanya logosentrisme dan fonosentrisme yang secara keseluruhan melahirkan oposisi biner dan cara-cara berpikir lain yang bersifat hierarkis dikotomis (Ratna, 2010). Dengan kata lain, dekonstruksi membiarkan makna bersifat ambigu dan menantang segala kemungkinan makna karena yang diinginkan dekonstruksi adalah menghidupkan kekuatan-kekuatan tersembunyi yang turut membangun teks.

Dalam analisisnya, dekonstruksi Derrida selalu diawali dengan hal-hal yang tidak terpikirkan atau tidak boleh dipikirkan. Unsur-unsur yang akan dilacak kemudian dibongkar oleh Derrida bukanlah unsur yang remeh-temeh, tetapi unsur yang secara filosofis menjadi penentu atau unsur yang menjadikan teks tersebut menjadi filosofis (Norris, 2003). Teks tidak lagi dipandang sebagai tatanan makna yang utuh, tetapi arena pergulatan yang terbuka atau bebas. Yang dilacak oleh Derrida bukan penataan yang secara sadar atau prosedur yang logis, tetapi tatanan yang tidak disadari yang merupakan asumsi-asumsi tersembunyi yang terdapat di balik teks. Derrida ingin mengemukakan tekstualitas laten dalam sebuah teks. Realitas yang dianggap objektif, homogen, singular, didekonstruksi sehingga realitas itu terlihat dengan jelas menjadi plural, heterogen, dan fragmentaris (Siregar, 2019).

Persoalan lain dalam dekonstruksi adalah penggembosan terhadap narasi besar. Sesuatu yang telah berlaku lama, tertata, kemudian muncul sebagai sesuatu yang baru yang menolak atau bahkan sama sekali bertolak belakang dengan apa yang selama ini sudah tertanam kukuh, baik di bidang sosial, politik, agama, budaya, atau sastra. Hal ini sejalan dengan Barker (dalam Siregar, 2019) yang menjelaskan bahwa hal-hal yang dilakukan dalam dekonstruksi adalah membongkar atau memisahkan untuk menemukan dan mengungkapkan berbagai asumsi, strategi retoris, dan ruang kosong teks.

Dekonstruksi bukanlah hanya membongkar saja sampai habis dan membiarkannya begitu saja. Agar dekonstruksi berguna untuk kemajuan masyarakat, diperlukan suatu tindakan baru dan tindakan itu disebut rekonstruksi. Rekonstruksi merupakan penataan secara terus-menerus struktur yang juga didekonstruksi secara terus-menerus. Dengan demikian, proses dekonstruksi harus dilanjutkan oleh rekonstruksi.

Penataan bukan hanya sekali dilakukan, tetapi dilakukan secara terus-menerus. Selain itu, dalam dekonstruksi diperlukan tenggang waktu (time span) bagi hidupnya struktur beserta konsensus yang membangunnya. Untuk memahami timbulnya teori dekonstruksi yang dipopulerkan Derrida, pembaca harus mengerti strukturalisme. Penerapan dekonstruksi yang dilakukan Derrida adalah menitikberatkan pada hal-hal yang kecil. Untuk menyingkap yang ditutupi itu, perlu diadakan suatu cara dengan dekonstruksi. Dengan demikian, dekonstruksi yang dimaksud oleh Derrida bukan untuk mencari kebenaran atau yang paling benar dan menghancurkan yang salah, tetapi mendekonstruksi secara terus menerus tanpa henti.

\subsection{Kerangka Berpikir}

Penelitian ini didasarkan atas masalah yang berkaitan dengan eksistensi cerita rakyat Indonesia saat ini di tengah gempuran arus globalisasi. Hal ini menjadi penting untuk 
dipertahankan agar generasi muda Indonesia tidak melupakan salah satu kekayaan bangsa Indonesia, yakni cerita rakyat. Beberapa upaya yang sudah dilakukan di antaranya mengalihwahanakan cerita rakyat yang sifatnya lisan menjadi bentuk lain, seperti buku bergambar, foto berkisah, anime, dan video animasi. Bahkan, akhir-akhir ini, beberapa iklan televisi mengambil konsep cerita rakyat dalam penyajiannya.

Hal inilah yang dilakukan PT Lasallefood Indonesia dengan menghadirkan kembali salah satu produk andalannya, yakni sirop Marjan dengan tema cerita rakyat Indonesia. Cerita rakyat Indonesia yang semula merupakan produk budaya tradisional didekonstruksi menjadi iklan sirop. Selain itu, strategi kreatif iklan dalam memunculkan brand awareness-nya kepada penonton juga akan terlihat meski dalam kemasan cerita rakyat. Untuk lebih jelasnya, berikut adalah kerangka berpikir dari penelitian ini.

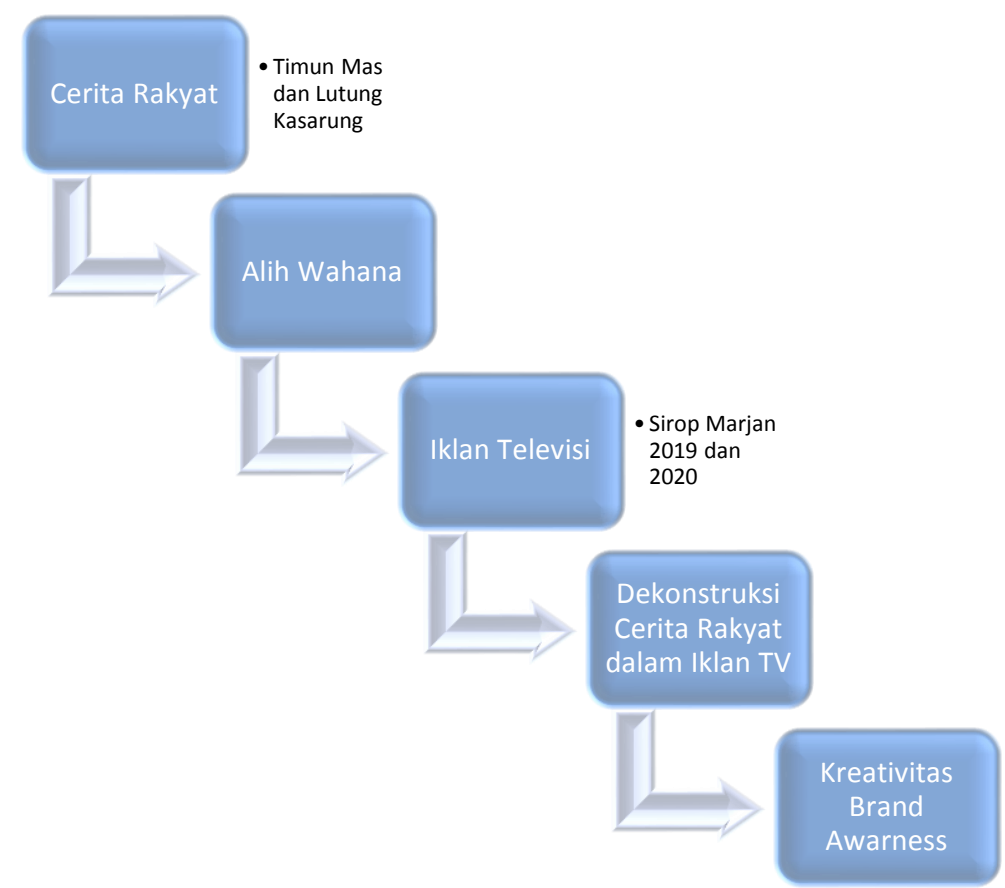

Gambar 1. Kerangka Berpikir Penelitian

\section{METODE PENELITIAN}

Penelitian ini merupakan jenis penelitian kualitatif. Metode yang digunakan adalah metode deskriptif kualitatif yang ditopang oleh teori dekonstruksi Derrida. Sebagai cara membaca yang baru, dekonstruksi dapat dilakukan, misalnya, dengan memahami dan mengkaji sesuatu yang semula dianggap kurang penting, seperti tokoh sekunder, tema minor, dan sebagainya, bahkan pada ruang-ruang kosong sehingga memengaruhi seluruh isi teks. Dalam hal ini, dekonstruksi dapat "mendobrak" pola-pola baku yang berlaku atau konstruksi tertentu untuk menghasilkan konstruksi baru, termasuk logika peristiwa dalam sebuah cerita.

Cerita rakyat yang dianalisis adalah cerita rakyat Indonesia yang terdapat dalam iklan Sirop Marjan, yakni Timun Mas edisi tahun 2019 dan Lutung Kasarung edisi tahun 2020. Data dalam penelitian ini adalah cerita rakyat Timun Mas dan Lutung Kasarung yang terdapat dalam iklan televisi sirop Marjan yang terdokumentasikan dalam Youtube (http://youtube.com/watch?v=nryLcxXHkG0, diakses tanggal 1 Juni 2020). Sementara itu, sumber cerita rakyat yang akan dijadikan rujukan dalam penelitian ini adalah cerita rakyat yang terdapat dalam akun Youtube Dongeng Kita. Selain memiliki jumlah subscriber terbanyak, yakni 1,5 juta 
subscriber pada tahun 2020, dari akun-akun lain yang serupa, akun Youtube Dongeng Kita juga konsisten menyajikan dongeng atau cerita rakyat Indonesia lainnya.

Teknik pengumpulan data menggunakan teknik pustaka dan teknik simak. Teknik pustaka merupakan teknik yang menggunakan sumber-sumber data tertulis untuk mengolah data. Sementara itu, teknik simak berarti sebagai instrumen untuk melakukan penyimakan secara cermat, menggunakan segala kemampuan pancaindra, terarah, dan teliti terhadap sumber data. Keabsahan data dilakukan dengan triangulasi sumber data, teori, dan antarpeneliti (Moleong, 2017). Teknik dan prosedur yang digunakan untuk mengumpulkan data terdiri atas teknik pustaka yang merupakan teknik yang menggunakan sumber-sumber data tertulis untuk mengolah data dan teknik simak yang berarti sebagai instrumen untuk melakukan penyimakan secara cermat, menggunakan segala kemampuan pancaindra, terarah, dan teliti terhadap sumber data, yakni cerita rakyat dalam iklan televisi sirop Marjan.

Teknik analisis data dilakukan dengan terlebih dahulu membandingkan konten cerita rakyat Timun Mas serta Purbasari dan Lutung Kasarung yang terdapat dalam akun Youtube Dongeng Kita dan Iklan Sirop Marjan. Langkah selanjutnya adalah melihat oposisi biner di antara kedua cerita tersebut kemudian menganalisis struktur cerita keduanya. Berdasarkan hasil analisis, akan terlihat adanya dekonstruksi cerita rakyat dalam iklan Sirop Marjan. Dekonstruksi tersebut dapat dijadikan acuan untuk melihat strategi kemunculan brand Sirop Marjan dalam iklan pada setiap episodenya. Selanjutnya, pola-pola kemunculan brand itu dimasukkan ke dalam tabel analisis.

\section{HASIL DAN PEMBAHASAN}

Fokus utama dari penelitian ini adalah dekonstruksi cerita rakyat Indonesia dalam iklan televisi, yakni Sirop Marjan yang terdokumentasikan dalam Youtube. Iklan cerita rakyat yang akan diteliti berkaitan dengan kemunculan brand dalam cerita Timun Mas dan Lutung Kasarung yang ditayangkan pada tahun 2019 dan 2020. Adapun yang menjadi rujukan cerita asli dari Timun Mas dan Lutung Kasarung mengacu pada akun Youtube Dongeng Kita.

\subsection{Dekonstruksi Cerita Rakyat Timun Mas dalam Iklan Televisi Marjan}

Secara garis besar, cerita Timun Mas versi iklan Marjan ini divisualisasikan ke dalam tiga episode dalam bentuk cerita bersambung. Pada episode pertama, dijelaskan tentang awal kelahiran Timun Mas, Timun Mas mulai tumbuh dewasa, dan kedatangan Buto Ijo untuk menagih janji. Episode kedua menjelaskan perkelahian antara Timun Mas dan Buto Ijo yang ditandai dengan pengejaran Buto Ijo terhadap Timun Mas. Episode ketiga masih menjelaskan pengejaran Timun Mas dan diakhiri dengan perdamaian antara Timun Mas dan Buto Ijo. Dalam tiga episode inilah terlihat adanya dekonstruksi yang berkaitan dengan kemunculan brand Sirop Marjan.

Pada awal kelahiran Timun Mas, visualisasi iklan yang disajikan berupa gambar animasi. Di dalamnya, sang narator yang diwakili oleh suara perempuan bercerita tentang sepasang suami istri yang menginginkan anak. Lalu, raksasa datang dan memberikan bibit ketimun. Bibit ketimun yang ditanam tumbuh semakin besar. Tak lama kemudian, Timun Mas lahir. Animasi tersebut dikemas secara menarik dengan mengambil latar pedesaan. Secara umum, cerita dalam episode ini tidak jauh berbeda dengan cerita aslinya. Hanya saja, pada bagian ini, plot iklan dibuat lebih singkat dari cerita aslinya karena terbatas durasi.

Cerita selanjutnya tidak digambarkan dengan animasi, tetapi melalui adegan antartokohtokohnya. Seiring berjalannya waktu, Timun Mas tumbuh semakin besar. Selain cantik dan cerdas, Timun Mas digambarkan sebagai anak yang cekatan, terampil, serta patuh pada ibunya. Ia senantiasa membantu ibunya berdagang di pasar. Pada peristiwa ini dekonstruksi cerita terlihat dari pengembangan alur cerita yang memunculkan brand Sirop Marjan. Kemunculan brand itu diawali 
ketika Timun Mas memperlihatkan kemampuan bela dirinya di sekitar dagangan ibunya. Hal itu membuat banyak orang tertarik untuk melihat atraksi yang dilakukan Timun Mas. Dalam kondisi itulah, sang ibu muncul dengan membawa Sirop Marjan rasa cocopandan dengan aneka buah segar di dalamnya untuk bisa dinikmati banyak orang (Gambar 1). Pada momen inilah sirop Marjan muncul sebagai pelepas dahaga pada siang hari atas aktivitas yang dilakukan orang-orang di pasar tersebut (Gambar 2). Aktivitas ketika sang ibu menyajikan sirop Marjan ini merupakan bentuk pengembangan plot sebagai strategi untuk memunculkan merek (brand) Marjan itu sendiri, khususnya rasa cocopandan (Gambar 3). Tentu saja peristiwa ini sangat berbeda dengan cerita asli yang selama ini berkembang.

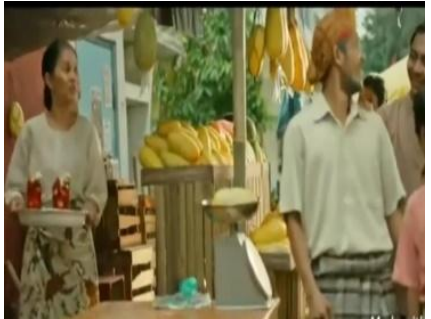

Gambar 1. Sirop Marjan yang disajikan Ibu Timun Mas. Sumber: Youtube (2020)

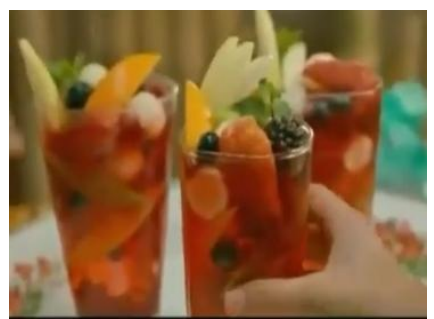

Gambar 2. Sirop Marjan cocopandan sebagai pelepas dahaga pada siang hari. Sumber: Youtube (2020)

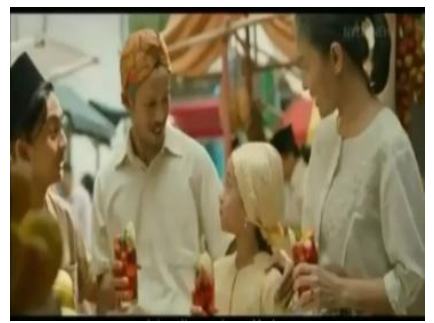

Gambar 3. Orang-orang di pasar menikmati Marjan Cocopandan. Sumber: Youtube (2020)

Saat sedang menikmati sirop Marjan, Buto Ijo tiba-tiba datang dan mengacaukan suasana saat itu. Peristiwa berkejar-kejaran antara Buto Ijo dan Timun Mas pun dimulai lalu berlanjut hingga episode kedua. Paham dengan bahaya yang akan dihadapi anaknya, Ibu Timun Mas meminta anaknya tersebut untuk melarikan diri dari Buto Ijo. Tak lupa, sang ibu memberikannya beberapa benda ajaib.

Dalam episode kedua ini, visualisasi iklan lebih terarah pada aktivitas fisik yang dilakukan Timun Mas dalam menghadapi kejaran Buto Ijo, seperti berlari atau melompat. Hal ini juga terjadi pada cerita aslinya. Namun, dalam iklan, pengejaran itu berlangsung cukup lama, yakni satu bulan lamanya hingga bulan puasa tiba. Dekonstruksi cerita pada episode ini terlihat ketika Timun Mas berhasil mengikat Buto Ijo dengan salah satu benda ajaib pemberian ibunya. Hal itu terjadi menjelang berbuka puasa. Tak lama kemudian, Timun Mas pun berbuka puasa bersama dengan beberapa warga desa di sana (Gambar 4). Pada momen berbuka puasa inilah sirop Marjan kembali dihadirkan dengan menampilkan rasa lainnya, yakni melon. Beragam minuman Marjan dihidangkan, mulai dari sirop hingga es buah (Gambar 5). Berbuka puasa dengan Sirop Marjan adalah sesuatu yang menyegarkan dan mampu mengakrabkan suasana. Buktinya, warga di sana tetap berbaik hati pada Buto Ijo. Mereka memberikan minum kepada Buto Ijo dan mengajaknya berbuka puasa. Bahkan, ada yang berfoto bersama seolah-olah Buto Ijo bukanlah sesuatu yang ditakuti (Gambar 6).

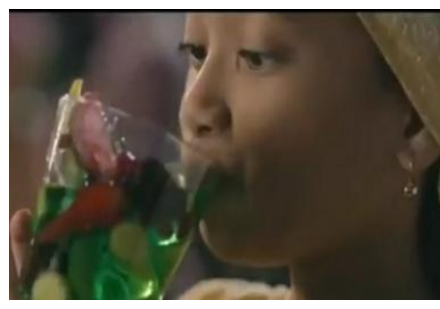

Gambar 4. Timun Mas berbuka puasa dengan Sirop Marjan rasa melon. Sumber: Youtube (2020)

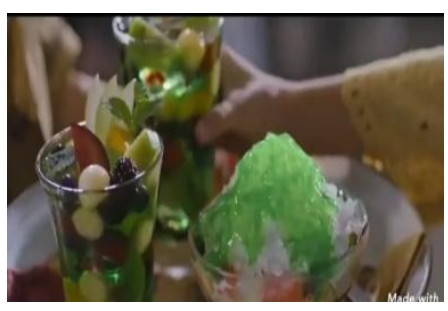

Gambar 5. Aneka olahan Sirop Marjan rasa melon. Sumber: Youtube (2020)

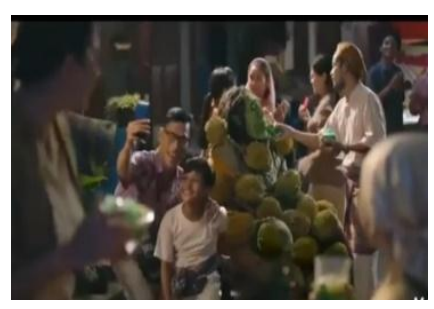

Gambar 6. Timun Mas, warga, dan Buto Ijo berbuka puasa dengan menikmati Marjan rasa melon. Sumber: Youtube (2020) 
Pada episode ketiga, iklan yang dihadirkan masih berkaitan dengan konflik yang terjadi antara Timun Mas dan Buto Ijo. Jalan cerita yang ditampilkan dalam bagian ini hampir semuanya telah didekonstruksi. Setelah berbuka puasa, tali yang mengikat Buto Ijo lepas. Timun Mas kembali berlari menghindari Buto Ijo. Peristiwa itu terjadi selama beberapa hari. Hingga akhirnya Timun Mas terdesak. Dalam kondisi tersebut, ia mengeluarkan senjata terakhirnya, yakni terasi yang kemudian berubah menjadi lumpur isap dan siap menelan Buto Ijo. Namun, apa yang terjadi? Timun Mas tidak tega. Ia segera meminta bantuan warga yang sedang berkumpul dan mempersiapkan perayaan Idulfitri untuk menyelamatkan Buto Ijo (Gambar 7). Alhasil, Buto Ijo berhasil selamat. Ia mengucapkan terima kasih kepada Timun Mas. Keduanya pun berdamai. Ketika Hari Lebaran tiba, Buto Ijo beserta keluarga Timun Mas dan seluruh warga menikmati Sirop Marjan bersama-sama dengan berbagai macam olahan dan varian rasa (Gambar 8)

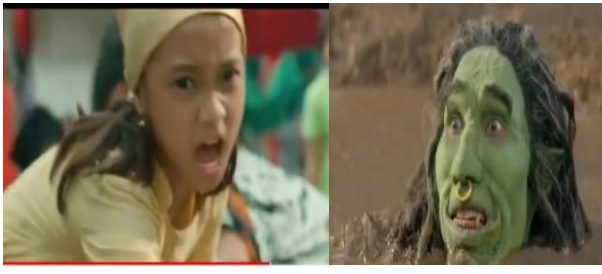

Gambar 7. Timun Mas menyelamatkan Buto Ijo. Sumber: Youtube (2020)

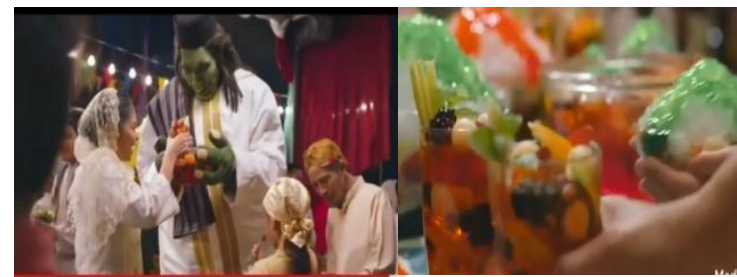

Gambar 8. Timun Mas dan Buto Ijo menikmati Sirop Marjan beraneka rasa di Hari Lebaran. Sumber: Youtube (2020)

Pada momen Idulfitri brand Sirop Marjan kembali muncul sebagai salah satu sajian yang menyegarkan. Dalam konteks yang lebih luas, misalnya, di masyarakat, sirop seolah menjadi ciri khas minuman yang perlu ada saat Lebaran, tak terkecuali Sirop Marjan. Kemunculan brand Marjan di hari raya sekaligus sebagai akhir dari episode Timun Mas.

Tentu saja akhir dari cerita ini berbeda dengan versi aslinya. Cerita yang berkembang selama ini adalah Buto Ijo mati di tangan Timun Mas. Sementara dalam iklan Marjan, semuanya berakhir bahagia. Timun Mas pun tidak ingin memanfaatkan ketidakberdayaan Buto Ijo untuk membunuhnya. Perlunya sikap saling memaafkan merupakan pesan yang ingin disampaikan dari iklan ini. Kejahatan yang dilakukan seseorang sebaiknya dibalas dengan kebaikan. Untuk lebih jelasnya, analisis dekonstruksi yang berkaitan dengan kemunculan brand Sirop Marjan disajikan dalam tabel berikut.

Tabel 1. Tabel Analisis Dekonstruksi Cerita Rakyat Timun Mas dalam Iklan Sirop Marjan

\begin{tabular}{|c|c|c|c|}
\hline \multirow[b]{2}{*}{ No. } & \multirow{3}{*}{$\begin{array}{l}\text { Deskripsi Data } \\
\text { (Episode 1) } \\
\text { Kebersamaan Timun Mas dan } \\
\text { ibunya }\end{array}$} & \multicolumn{2}{|c|}{ Dikotomi Oposisi Biner } \\
\hline & & $\begin{array}{c}\text { Pemaknaan Awal Cerita Timun } \\
\text { Mas dalam Youtube Dongeng Kita }\end{array}$ & $\begin{array}{c}\text { Dekonstruksi Cerita Timu Mas } \\
\text { dalam Iklan Marjan }\end{array}$ \\
\hline \multirow[t]{2}{*}{1.} & & $\begin{array}{l}\text { Timun Mas tumbuh sebagai anak } \\
\text { yang berbakti pada ibunya. Ia selalu } \\
\text { membantu ibunya di kebun. }\end{array}$ & $\begin{array}{l}\text { a) Timun Mas tumbuh sebagai anak } \\
\text { yang berbakti pada ibunya. Ia selalu } \\
\text { membantu ibunya berdagang di pasar }\end{array}$ \\
\hline & & & $\begin{array}{l}\text { b) Selesai berdagang, sang ibu } \\
\text { menyuguhkan sirop Marjan rasa } \\
\text { cocopandan sebaga sajian yang } \\
\text { menyegarkan di siang hari untuk } \\
\text { dinikmati banyak orang di pasar }\end{array}$ \\
\hline 2. & $\begin{array}{l}\text { (Episode 2) } \\
\text { Kedatangan Buto Ijo } \\
\text { (Raksasa) untuk menagih janji }\end{array}$ & $\begin{array}{l}\text { a) Raksasa mendatangi rumah } \\
\text { Timun Mas untuk menagih janji }\end{array}$ & $\begin{array}{l}\text { a) Buto Ijo mencari Timun Mas dan } \\
\text { mengacau di pasar ketika orang-orang } \\
\text { sedang menikmati Sirop Marjan }\end{array}$ \\
\hline & & b) Raksasa mengejar Timun Mas & \\
\hline
\end{tabular}


3. (Episode 3)

Akhir kisah Timun Mas dan

Buto Ijo (Raksasa) a) Timun Mas berhasil mengalahkan Raksasa dengan benda-benda ajaib miliknya

b) Raksasa mati tenggelam dalam lumpur ganas b) Buto Ijo mengejar Timun Mas

c) Timun Mas berhasil mengikat Buto Ijo dengan tali ajaibnya

d) Timun Mas, sang ibu, warga sekitar, dan Buto Ijo berbuka puasa dengan Sirop Marjan rasa melon

a) Timun Mas berhasil mengalahkan Buto Ijo dengan benda-benda ajaibnya

b) Timun Mas beserta warga sekitar menolong Buto Ijo yang hampir tenggelam di lumpur isap.

c) Timun Mas dan Buto Ijo berdamai

d) Timun Mas, Buto Ijo, sang ibu, dan warga sekitar menikmati Sirop Marjan di Hari Lebaran.

Tabel tersebut menjelaskan bahwa cerita rakyat Timun Mas yang ada dalam iklan Marjan mengalami dekonstruksi cerita, khususnya pengembangan dari segi penokohan dan alur (plot) cerita dengan memunculkan brand Sirop Marjan. Secara umum, alur cerita tidak banyak berubah dan tidak menghilangkan unsur tradisional dari cerita rakyat tersebut. Namun, pada beberapa adegan, khususnya ketika Buto Ijo mengejar Timun Mas, terlihat pengembangan peristiwa sebagai bagian dari promosi sirop Marjan meski dengan durasi waktu yang terbatas.

Kemunculan brand tersebut adalah sesuatu yang logis jika dikaitkan dengan kondisi saat ini. Pertama, setelah beraktivitas dan badan mulai lelah, khususnya siang hari, orang membutuhkan air atau sesuatu yang menyegarkan. Sirop Marjan dapat dijadikan salah satu alternatif untuk melepas dahaga dan memulihkan tenaga. Hal ini tecermin dalam episode pertama ketika Ibu Timun Mas menyajikan Marjan untuk dinikmati bersama dengan orang-orang di pasar. Kedua, ketika berbuka puasa dianjurkan berbuka dengan yang manis untuk mengembalikan energi yang hilang. Sirop Marjan dapat dijadikan pilihan menu berbuka, baik itu dalam bentuk minuman segar, campuran takjil, atau es buah. Ketika waktunya berbuka puasa, berbukalah terlebih dahulu. Tinggalkan sejenak segala aktivitas yang mengganggu. Itulah yang dilakukan Timun Mas dan Buto Ijo pada episode kedua. Ketiga, pada Hari Raya Idulfitri, sirop menjadi salah satu minuman yang perlu disajikan bersama dengan kue-kue lainnya. Hal inilah yang coba disampaikan iklan Marjan pada episode ketiga. Lebaran adalah momen sakral untuk saling memaafkan. Adanya perubahan pada akhir cerita Timun Mas sesuai dengan slogan dari iklan Marjan itu sendiri, yakni "Inilah kisah Marjan Merayakan Kebaikan". Perdamaian antara Timun Mas dan Buto Ijo adalah wujud dari kebaikan itu sendiri.

\subsection{Dekonstruksi Cerita Rakyat Lutung Kasarung dalam Iklan Televisi Marjan}

Pada tahun berikutnya (2020), Marjan mengeluarkan iklan terbarunya dengan konsep yang sama, tetapi cerita yang berbeda, yakni kisah Purbasari dan Lutung Kasarung yang berasal dari Jawa Barat. Cerita rakyat Lutung Kasarung versi iklan Marjan ini divisualisasikan ke dalam tiga episode dalam bentuk cerita bersambung. Pada episode pertama, dijelaskan tentang pemberian takhta kerajaan dari sang raja kepada si bungsu yang bernama Purbasari, kedatangan penyihir jahat untuk mengutuk Purbasari karena suruhan dari kakak tertua, yakni Purbararang, dan kepergian Purbasari ke hutan. Episode kedua menjelaskan pertemuan antara Purbasari dan Lutung Kasarung di hutan hingga menjadi teman baik, hilangnya kutukan Purbasari dan Lutung Kasarung, serta kedatangan kembali Purbasari dan Lutung Kasarung ke kerajaan untuk menghancurkan penyihir 
jahat. Sementara episode ketiga, hal yang digambarkan adalah kembalinya takhta kerajaan kepada Purbasari dan kerajaan kembali seperti sedia kala. Dalam tiga episode inilah terlihat adanya dekonstruksi yang berkaitan dengan kemunculan brand Sirop Marjan.

Iklan pada episode pertama ini berupa adegan pemberian takhta kerajaan dari raja kepada Purbasari. Pada peristiwa ini, dekonstruksi terlihat dari pengembangan alur cerita yang memunculkan brand Sirop Marjan. Acara pemberian takhta tersebut dihadiri oleh seluruh petinggi kerajaan. Mereka semua bersuka cita sembari menikmati sirop Marjan rasa cocopandan dengan aneka buah di dalamnya (Gambar 9). Kehadiran brand ini disesuaikan dengan kondisi yang sedang terjadi, yakni pada sebuah acara besar kerajaan. Pada bagian ini, plot dalam iklan juga dibuat lebih singkat dari cerita aslinya karena terbatas durasi. Kisah tentang siapa sang raja, memerintah di kerajaan apa, dan siapa saja nama ketujuh putrinya tidak disinggung sama sekali seperti dalam cerita aslinya.

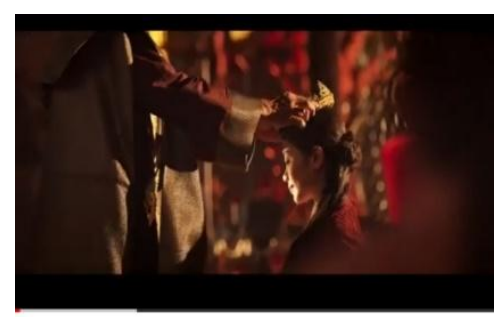

Gambar 9. Raja memberikan takhta kepada Purbasari. Sumber: Youtube (2020)

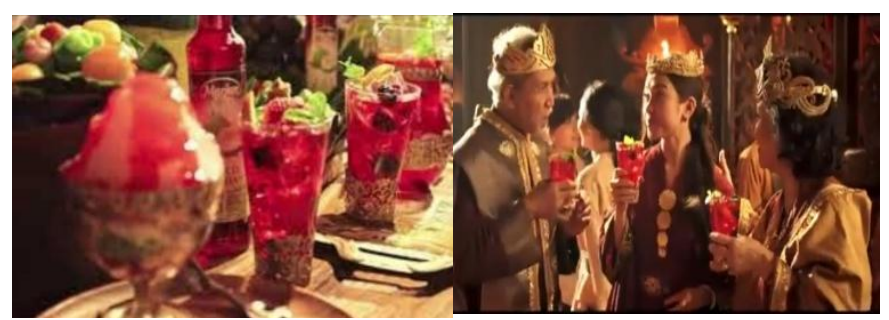

Gambar 10. Sukacita orang-orang kerajaan dalam menikmati Marjan cocopandan. Sumber: Youtube (2020)

Ketika semua orang sedang bersuka cita menikmati Marjan rasa cocopandan, peristiwa tak terduga pun terjadi. Terpilihnya sang putri bungsu untuk naik takhta ternyata menyulut kecemburuan kakak tertua yang bernama Purbararang. Bahkan, ia sampai tega mencelakai adiknya sendiri. Purbasari mendapat kutukan penyakit kulit yang menyebabkan ia harus pergi meninggalkan istana. Jalan cerita yang disajikan pada bagian ini sama persis dengan cerita aslinya.

Episode kedua dalam iklan tersebut menggambarkan hari-hari yang dilalui Purbasari di hutan. Dalam pengasingannya itu, Purbasari bertemu dengan manusia kera yang juga terkena kutukan. Manusia kera itu bernama Lutung Kasarung. Singkat cerita, keduanya menjadi akrab. Pada peristiwa ini, dekonstruksi cerita terlihat dari munculnya brand Sirop Marjan sebagai simbol keakraban antara Purbasari dan Lutung Kasarung (Gambar 11). Keduanya menikmati Sirop Marjan rasa melon di hutan (Gambar 12). Dengan kekuatannya, Purbasari berhasil menyajikan olahan Sirop Marjan, yakni es buah. Pada iklan tersebut juga ditegaskan bahwa kutukan Purbasari dan Lutung Kasarung hilang setelah mereka menikmati sirop Marjan. Setelah kutukan keduanya hilang, mereka menuju ke kerajaan Purbasari.

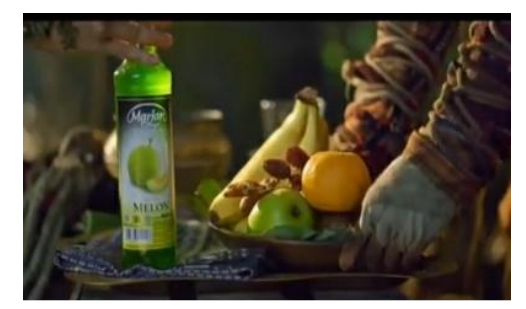

Gambar 11. Sirop Marjan rasa melon yang mengakrabkan Purbasari dan Lutung Kasarung. Sumber: Youtube (2020)

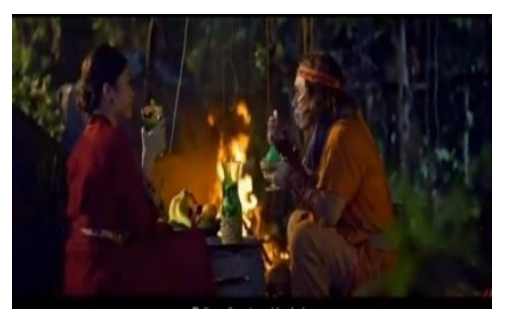

Gambar 12. Purbasari dan Lutung Kasarung menikmati Marjan rasa melon di hutan. Sumber: Youtube (2020) 
Pada episode ketiga, visualisasi yang disajikan lebih terfokus pada adegan pertarungan antara Purbasari dan Lutung Kasarung melawan penyihir jahat, suruhan Purbararang yang mengutuk Purbasari (Gambar 31). Dalam pertarungan tersebut, penyihir jahat kalah. Semua orang di kerajaan yang terkena kutuk, bebas kembali, termasuk Purbararang. Sang kakak pun meminta maaf. Kedamaian di kerajaan kembali tercipta. Jalan cerita yang digambarkan pada bagian ini juga sedikit berbeda dengan cerita aslinya. Selain dibuat lebih singkat, pertarungan antara Purbasari dan Lutung Kasarung merupakan bentuk pengembangan plot dari cerita ini. Dalam cerita aslinya, Purbasari dan Purbararang melakukan sayembara, mulai dari memasak, adu panjang rambut, dan adu ketampanan calon suami yang pada akhirnya dimenangkan Purbasari.

Akhir cerita yang ditampilkan dalam iklan tidak jauh berbeda dengan versi aslinya, yakni Purbasari memaafkan kesalahan kakaknya dan takhta dikembalikan kepada Purbasari. Namun, dalam iklan, kemunculan brand Marjan dihadirkan kembali pada akhir cerita. Perdamaian antara Purbasari dan Purbararang serta pengembalian takhta kerajaan kepada Purbasari dirayakan dengan menikmati segarnya Marjan dalam berbagai rasa dan olahannya (Gambar 13). Kebahagiaan orangorang istana terlihat ketika mereka menikmati Sirop Marjan (Gambar 14). Adegan ini menyiratkan bahwa Sirop Marjan adalah salah satu minuman khas kerajaan yang perlu disajikan pada acaraacara besar kerajaan.

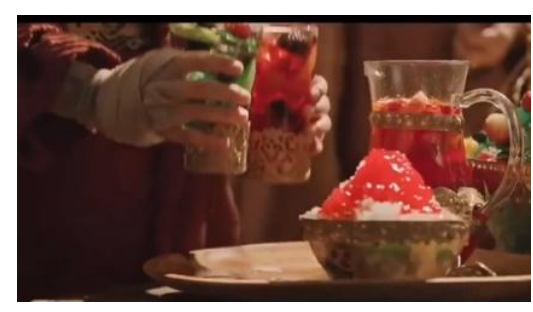

Gambar 13. Aneka varian rasa Sirop Marjan dihadirkan di kerajaan Purbasari. Sumber: Youtube (2020)

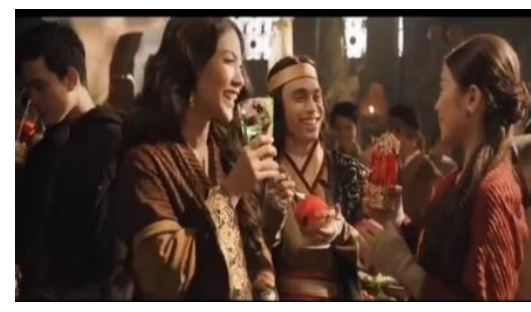

Gambar 14. Purbasari dan seluruh orang di kerajaan menikmati Marjan bersama. Sumber: Youtube (2020)

Tabel di bawah ini menjelaskan analisis dekonstruksi cerita rakyat Lutung Kasarung dalam iklan Marjan yang telah mengalami beberapa pengembangan dari segi penyajian kemenarikan cerita. Sama halnya seperti cerita rakyat Timun Mas, secara umum, alur cerita Lutung Kasarung tidak banyak berubah dan tidak menghilangkan unsur tradisional dari cerita rakyat tersebut. Inti dan pesan cerita tetap tersampaikan dengan baik dalam durasi waktu yang singkat. Strategi kemunculan merek Marjan juga ditampilkan pada momen-momen penting kerajaan. Marjan hadir untuk merayakan kebaikan, kebersamaan, dan keakraban.

Tabel 2. Tabel Analisis Dekonstruksi Cerita Rakyat Purbasari dan Lutung Kasarung dalam Iklan Sirop Marjan

\begin{tabular}{|c|c|c|c|}
\hline \multirow[b]{2}{*}{ No. } & \multirow[b]{2}{*}{ Deskripsi Data } & \multicolumn{2}{|c|}{ Dikotomi Oposisi Biner } \\
\hline & & $\begin{array}{c}\text { Pemaknaan Awal Cerita } \\
\text { Purbasari dan Lutung Kasarung } \\
\text { dalam Youtube Dongeng Kita }\end{array}$ & $\begin{array}{c}\text { Dekonstruksi Cerita Purbasari dan } \\
\text { Lutung Kasarung dalam Iklan } \\
\text { Marjan }\end{array}$ \\
\hline 1. & $\begin{array}{l}\text { (Episode 1) } \\
\text { Pemberian takhta kerajaan } \\
\text { kepada Purbasari }\end{array}$ & $\begin{array}{l}\text { a) Raja memberikan takhta kerajaan } \\
\text { kepada Purbasari } \\
\text { b) Purbararang kecewa dan } \\
\text { mengutuk Purbasari }\end{array}$ & $\begin{array}{l}\text { a) Pemberian takhta kerajaan kepada } \\
\text { Purbasari disaksikan oleh seluruh } \\
\text { petinggi kerajaan } \\
\text { b) Sirop Marjan rasa cocopandan } \\
\text { disajikan sebagai suguhan dalam acara } \\
\text { pemberian takhta kerajaan } \\
\text { c) Purbararang kecewa dan mengutuk } \\
\text { Purbasari }\end{array}$ \\
\hline 2. & (Episode 2) & Keakraban & a) Keakraban antara Purbasari dan \\
\hline
\end{tabular}


Pertemuan antara Purbasari dan Lutung Kasarung di hutan

3. (Episode 3)

Akhir kisah Purbasari dan Lutung Kasarung
Purbasari dan Lutung Kasarung

b) Kutukan Purbasari hilang dan menjadi cantik kembali setelah mandi di telaga ajaib

a) Sayembara antara Purbasari dan Purbararang dimenangkan oleh Purbasari

b) Purbararang meminta maaf dan Purbasari kembali memerintah kerajaan
Lutung Kasarung ditandai dengan kehadiran Sirop Marjan rasa melon dengan beraneka macam sajiannya

b) Kutukan Purbasari dan Lutung Kasarung hilang setelah meminum Sirop Marjan

a) Purbasari dan Lutung Kasarung menang melawan penyihir jahat

b) Permintaan maaf Purbararang dan kembalinya takhta kerajaan kepada Purbasari

c) Sirop Marjan beraneka rasa disajikan untuk merayakan kembalinya kerajaan kepada Purbasari

\subsection{Brand Awareness dalam Iklan Televisi Sirop Marjan}

Iklan merupakan bentuk upaya yang digunakan untuk mempromosikan produk-produk tertentu. Salah satu hal yang perlu diperhatikan adalah membangun kesadaran merek (brand awareness). Adanya kesadaran merek dapat menjadi ciri khas dari sebuah produk agar dikenal dan mudah diingat konsumen (Oktafiandi, 2018).

Marjan merupakan salah satu sirop yang menjadi pioneer di pangsa pasar sirop sekelasnya dan mampu memunculkan brand awareness tersebut. Sebagai produk seasonal, Marjan senantiasa memanfaatkan momen spesial, seperti Ramadhan dan Idulfitri untuk kembali mempromosikan produknya. Tak heran jika kehadiran iklan ini dapat dijadikan penanda bahwa bulan puasa dan hari raya Lebaran akan segera tiba.

Kemunculan brand Marjan dalam adegan cerita juga sesuai dengan kondisi yang ada di cerita tersebut. Marjan selalu dihadirkan dalam setiap momen kebaikan entah itu yang bersifat kebersamaan, keakraban, atau perayaan. Bahkan, pada beberapa adegan yang memunculkan ketegangan, brand Marjan ini selalu dihadirkan dengan tujuan agar suasana kembali santai dan menyenangkan. Varian rasa yang ditonjolkan pun sudah sesuai dengan porsinya masing-masing. Marjan sangat cerdas dalam menampilkan keunggulan rasa utamanya, yakni cocopandan dan melon. Untuk lebih jelasnya, tabel berikut akan menjelaskan pola kemunculan brand Marjan dalam setiap episodenya di cerita rakyat Timun Mas dan Lutung Kasarung.

Tabel 3. Pola Kemunculan Brand Marjan dalam Cerita Rakyat Timun Mas

\begin{tabular}{lll}
\hline No. & Rangkaian Cerita & Kemunculan Brand Marjan \\
\hline 1. & Episode (1) & Sirop Marjan rasa cocopandan dihadirkan di sela-sela \\
& Kebersamaan Timun Mas bersama ibunya & $\begin{array}{l}\text { aktivitas saat Timun Mas membantu ibunya berdagang di } \\
\text { pasar. Situasi yang terlihat adalah siang hari dan ramai } \\
\text { dengan orang-orang pasar. Sirop Marjan disajikan untuk } \\
\text { dinikmati bersama-sama sebagai pelepas dahaga. }\end{array}$ \\
& & Sirop Marjan rasa melon dihadirkan untuk berbuka \\
2. & Episode (2) & puasa. Dalam konteks ini, pengejaran Buto Ijo terhadap \\
& Kedatangan Buto Ijo untuk menagih janji & Timun Mas berlangsung sebulan lamanya hingga \\
& & Ramadhan tiba. Menjelang berbuka, Timun Mas berhasil \\
& mengikat Buto Ijo. Sampai di rumah, Timun Mas, sang \\
& ibu, dan warga sekitar mengajak Buto Ijo untuk berbuka \\
& puasa bersama dengan menikmati Sirop Marjan rasa \\
& melon. \\
& Sirop Marjan dengan beraneka rasa dan olahannya \\
\hline
\end{tabular}


Tabel 4. Pola Kemunculan Brand Marjan dalam Cerita Rakyat Lutung Kasarung

\begin{tabular}{|c|c|c|}
\hline No. & Rangkaian Cerita & Kemunculan Brand Marjan \\
\hline 1. & $\begin{array}{l}\text { Episode (1) } \\
\text { Pemberian takhta kerajaan dari raja kepada si bungsu, } \\
\text { Purbasari }\end{array}$ & $\begin{array}{l}\text { Sirop Marjan rasa cocopandan dihadirkan } \\
\text { ketika acara pergantian takhta di istana. } \\
\text { Seluruh orang-orang kerajaan bersuka cita } \\
\text { sembari menikmati kesegaran Sirop Marjan. }\end{array}$ \\
\hline 2. & $\begin{array}{l}\text { Episode (2) } \\
\text { Pertemuan antara Purbasari dan Lutung Kasarung di hutan }\end{array}$ & $\begin{array}{l}\text { Sirop Marjan rasa melon dihadirkan untuk } \\
\text { mengakrabkan persahabatan antara Purbasari } \\
\text { dan Lutung Kasarung. Kutukan Purbasari dan } \\
\text { Lutung Kasarung hilang setelah meminum } \\
\text { Sirop Marjan }\end{array}$ \\
\hline 3. & $\begin{array}{l}\text { Episode (3) } \\
\text { Akhir kisah Purbasari dan Lutung Kasarung }\end{array}$ & $\begin{array}{l}\text { Sirop Marjan beraneka rasa dan olahan } \\
\text { disajikan untuk merayakan kembalinya takhta } \\
\text { kerajaan kepada Purbasari. Seluruh orang- } \\
\text { orang kerajaan kembali bersuka cita sembari } \\
\text { menikmati kesegaran Sirop Marjan. }\end{array}$ \\
\hline
\end{tabular}

Keberadaan iklan Marjan yang ditampilkan secara modern tidak menggeser kemenarikan cerita sebagai inti dari iklan yang ingin disimak masyarakat. Alur cerita rakyat yang dijadikan iklan pun tidak banyak berubah karena masih mempertahankan cerita aslinya. Dalam cerita Timun Mas, sang ibu menyajikan Marjan sebagai pelepas dahaga di siang hari setelah beraktivitas, ketika berbuka puasa, dan hari Idulfitri. Sementara dalam cerita Lutung Kasarung, Marjan dihadirkan ketika perayaan pergantian takhta kerajaan, keakraban antara Purbasari dan Lutung Kasarung saat mereka di hutan, serta ketika kerajaan sudah kembali aman dan damai. Munculnya merek Marjan dalam berbagai momen ini sangat masuk akal karena pada momen-momen itulah kita butuh air atau sesuatu yang dapat diminum sebagai pelepas dahaga. Rasa sirop yang disajikan dari kedua iklan tersebut juga dihadirkan secara konsisten, yakni rasa cocopandan di awal iklan, rasa melon di pertengahan iklan, dan penyajian kedua rasa di penutup iklan. Kemunculan brand Marjan sebanyak tiga kali merupakan strategi penempatan merek yang pas. Di samping mencari keuntungan dari produknya, iklan Marjan dapat dijadikan sarana edukasi melalui pesan-pesan yang ada dalam setiap cerita rakyat yang ditampilkan.

\subsection{Diskusi}

Berdasarkan analisis tersebut, dapat dipahami bahwa selain untuk meningkatkan penjualan atau memperkuat brand image sebuah produk, iklan dapat juga berfungsi sebagai media untuk melestarikan budaya. Apa yang dilakukan perusahaan iklan Marjan adalah sebuah terobosan baru untuk memperkenalkan kembali beberapa kekayaan bangsa, khususnya cerita rakyat. Di tengah gempuran perkembangan zaman yang semakin berkembang, Marjan berani melakukan terobosan baru atas sesuatu hal yang bersifat tradisional. Hasilnya pun bisa diterima masyarakat.

Kemunculan brand Marjan dalam beberapa adegan juga sesuai dengan kondisi yang ada di cerita tersebut. Marjan selalu dihadirkan dalam setiap momen kebaikan entah itu yang bersifat kebersamaan, keakraban, atau perayaan. Bahkan, adegan saat orang-orang meminum sirop Marjan pun dibuat untuk melunturkan ketegangan-ketegangan yang ada dalam cerita. Untuk varian rasa pun ditonjolkan sesuai dengan porsinya masing-masing. Marjan sangat cerdas dalam menampilkan keunggulan rasa utamanya, yakni cocopandan dan melon. 
Cerita rakyat yang dijadikan iklan secara alur cerita tidak banyak berubah karena masih mempertahankan cerita aslinya. Yang berbeda adalah media penyampaiannya karena ada selipan iklan dalam mempromosikan produk sirop Marjan. Keberadaan iklan Marjan yang ditampilkan secara modern tidak menggeser kemenarikan cerita sebagai inti dari iklan yang ingin disimak masyarakat. Dalam cerita Timun Mas, sang ibu menyajikan Marjan sebagai pelepas dahaga di siang hari setelah beraktivitas, ketika berbuka puasa, dan Hari Raya Idulfitri. Sementara dalam cerita Lutung Kasarung, Marjan dihadirkan ketika perayaan pergantian takhta kerajaan, keakraban antara Purbasari dan Lutung Kasarung saat mereka di hutan, serta ketika kerajaan sudah kembali aman dan damai. Munculnya merek Marjan dalam berbagai momen ini sangat masuk akal karena pada momen-momen itulah kita butuh air atau sesuatu yang dapat diminum sebagai pelepas dahaga.

Hal tersebut senada dengan Aminova (2017). Hasil penelitiannya menjelaskan bahwa Jepang merupakan salah satu negara modern yang secara konsisten selalu berusaha mempertahankan nilai budaya tradisionalnya (Aminova, 2017). Salah satu cara untuk mewujudkannya ialah dengan menampilkan unsur cerita rakyat Jepang tradisional ke dalam sebuah iklan telepon seluler yang diiklankan di televisi. Akan tetapi, secara kuantitatif tidak ada satupun dari iklan yang dianalisis menampilkan jalan cerita yang murni sesuai versi aslinya. Iklan tersebut mengembangkan plot cerita asli, bahkan telah menciptakan cerita baru yang beda dengan versi aslinya, meski tokoh yang ditampilkan masih sama. Kedua dilihat secara kualitatif, iklan tersebut merekonstruksi cerita rakyat dengan jalan mengambil/mengutip hanya beberapa plot saja dari keseluruhan plot cerita rakyat versi asli. Berbeda dengan iklan televisi pada sirop Marjan yang masih mempertahankan plot cerita aslinya.

Cerita rakyat selain dapat dialihwahanakan menjadi bentuk lain, seperti iklan televisi juga dapat dijadikan sebuah film Animasi, seperti penelitian yang telah dilakukan oleh Setyawan (Setyawan, 2013); iklan produk es krim seperti yang dilakukan oleh Oktafiandi (Oktafiandi, 2018); anime seperti penelitian yang dilakukan oleh Damayanti (Damayanti, 2018); dan pengembangan aplikasi berbasis mobile seperti yang dilakukan Yusa (Yusa, 2014). Dalam penelitannya, Yusa dkk (2014) telah mengembangkan aplikasi berbasis mobile (digitalisasi) untuk menyampaikan kearifan lokal melalui cerita rakyat Bali (Yusa, 2014). Sasaran dari penelitiannya adalah anak sekolah dasar.

Penyajian cerita rakyat dalam iklan diharapkan dapat membangun kesadaran merek penonton sehingga didapatkan strategi kreatifnya. Strategi kreatif dalam iklan bertujuan untuk merepresentasikan produk yang diiklankan. Pemanfaatan seni, khususnya seni sastra, sebagai medium visualisasi iklan merupakan strategi yang digunakan untuk menarik minat penonton (Permana, 2017). Pada kasus yang lain, cerita rakyat yang dijadikan animasi memiliki potensi yang baik karena telah dikenal di masyarakat. Akibatnya, mudah bagi pelaku film dalam menarik minat masyarakat untuk menontonnya. Hal itulah yang menjadi alasan pembuat iklan Sirop Marjan dalam membuat iklan yang mengangkat cerita rakyat pada dua tahun terakhir. Produk Sirop Marjan dan cerita rakyat yang diambil telah dikenal luas masyarakat, terutama cerita rakyat yang berasal dari Pulau Jawa yang mayoritas produk Marjan dikonsumsi di daerah ini. Cerita rakyat yang dialihwahanakan menjadi bentuk lain dinilai dapat mengeksplorasi ide-ide besar di dalamnya sebagai daya tarik pada media perubahan itu bahkan meningkatkan ketertarikan dan kecintaan masyarakat terhadap cerita rakkyat tersebut.

\section{PENUTUP}

Cerita rakyat yang keberadaannnya mulai dilupakan banyak generasi muda Indonesia kembali dihadirkan iklan Marjan secara unik dan menarik. Adanya perpaduan kebudayaan tradisional dan modern dalam iklan tersebut telah menghasilkan konsep cerita yang menarik untuk dinikmati. 
Dalam hal ini, Marjan telah "memperkenalkan" kembali beberapa cerita rakyat versi milenial ke layar kaca meski hanya beberapa menit.

Ada beberapa bagian dari cerita rakyat Timun Mas serta Purbasari dan Lutung Kasarung yang didekonstruksi sesuai dengan kebutuhan iklan sebagai sarana promosi. Dekonstruksi tersebut berkaitan dengan kemunculan brand Sirop Marjan dalam setiap episodenya. Meskipun ada beberapa pengembangan dari sisi penokohan dan alur cerita (plot), inti atau pesan dari iklan tersebut dapat tersampaikan dengan jelas. Latar yang disajikan juga sesuai dengan kondisi yang ada pada cerita aslinya, yakni pedesaan (dalam cerita Timun Mas) serta istana dan hutan (dalam cerita Lutung Kasarung). Semua itu ditampilkan secara lengkap dengan keseharian yang biasa dilakukan masyarakatnya termasuk pakaian yang dikenakan saat itu. Untuk penokohan dan perwatakan ada beberapa yang berubah, tetapi peran dari perubahan tokoh tersebut tidak memengaruhi esensi cerita rakyat yang disajikan. Sedikit humor juga disajikan sebagai pemanis dalam iklan tersebut. Sepanjang iklan itu berlangsung, kemunculan brand sirop Marjan tidak berlebihan, yakni satu kali di setiap episodenya khususnya pada momen- momen yang dianggap penting dan masuk akal. Selain kental dengan amanat, nilai-nilai moral, dan identitas budaya suatu daerah, cerita rakyat juga dapat digunakan sebagai sarana promosi atas produk-produk tertentu.

Kehadiran sebuah iklan selain untuk meningkatkan penjualan atau memperkuat brand image sebuah produk dapat juga berfungsi sebagai media untuk melestarikan budaya. Saran praktis bagi dunia periklanan di Indonesia dapat melakukan hal-hal yang dilakukan oleh perusahaan iklan Marjan. Iklan tersebut telah melakukan sebuah terobosan untuk memperkenalkan kembali beberapa kekayaan bangsa, khususnya cerita rakyat. Di tengah gempuran perkembangan zaman yang semakin berkembang, Marjan berani melakukan modernisasi atas sesuatu hal yang bersifat tradisional dengan visualisasi yang menarik. Selain itu, iklan Marjan versi cerita rakyat juga dapat dijadikan sarana edukasi untuk menyampaikan pesan-pesan moral.

Cerita tentang Timun Mas dan Lutung Kasarung dikonsep untuk menyuarakan kebaikan. Dengan bersatunya kebaikan, kekuatan jahat bisa dikalahkan. Hal positif lainnya yang dapat dipahami adalah ketika iklan tersebut ditonton oleh anak-anak yang belum mengetahui cerita aslinya, mereka dapat bertanya kepada orang tuanya terkait dengan kelengkapan cerita tersebut. Apabila orang tua lupa, mereka dapat mencarinya dari berbagai sumber atau literatur. Dengan demikian, suasana dialogis antara anak dan orang tua akan terbangun. Keberhasilan dalam menghidupkan kembali cerita rakyat dengan versi yang berbeda adalah bukti betapa kuatnya pesan yang ada dalam cerita tersebut. Dengan memanfaatkan perkembangan teknologi, cerita-cerita rakyat Indonesia -- bahkan mungkin bisa diterapkan pada kearifan lokal lainnya -- akan terlihat lebih dinamis dan mampu mengikuti perkembangan zaman. Alhasil, keberadaannya tidak akan hilang, tetap lestari, dan dikenang sepanjang masa sebagai salah satu warisan berharga bangsa ini. Untuk penelitian selanjutnya, dapat dilakukan penelitian alih wahana dari cerita rakyat ke iklan televisi atau penelitian tentang modernitas yang dilakukan pembuat iklan terhadap cerita rakyat.

\section{Ucapan Terima Kasih}

Penulis perlu menyampaikan ucapan terima kasih kepada pihak yang telah berkontribusi dalam penelitian ini, yaitu Universitas Terbuka dan Universitas Esa Unggul yang selalu melaksanakan Tri Dharma Perguruan Tinggi secara rutin sebagai marwah dari instansi kami berkarier.

\section{DAFTAR PUSTAKA}

Aminova, S. E. (2017). Konstruksi Cerita Rakyat Jepang (Foklor) dalam Iklan Televisi Produk Smartphone 
AU Tahun 2016. Jurnal Japanology, 5(1), 35-49.

Damayanti. (2018). Alih Wahana Cerita Rakyat Terjadinya Pulau Bali dari Buku Cerita Bergambar Menjadi Anime. Pustaka, XVIII(2), 118-125.

Damono, S. D. (2018). Alih Wahana. PT Gramedia Pustaka Utama.

Danandjaja, J. (2007). Folklor Indonesia: Ilmu Gosip, Dongeng, dan Lain-Lain. Pustaka Umum Grafiti.

Handayani, D. (2019). Representasi Budaya dalam Iklan (Analisis Semiotika Iklan Marjan Versi Tari Betawi dan Sepatu Roda). Jurnal Budaya Nusantara, 3(1), 12-22.

Hartati, M. S. dan D. (2019). Transformasi Cerita Rakyat Jamarun ke Pertunjukkan "Cahaya Memintas Malam/ The Light Within A Night.” Jurnal Salaka, 1(1), 3-16.

Latif C.M., N. (2019). Eksplorasi Visual Cerita Rakyat Nusantara Dalam Foto Berkisah. Jurnal Dimensi DKV Seni Rupa Dan Desain, 4(2), 169-186. https://doi.org/10.25105/jdd.v4i2.5889

Lukitaningsih, A. (2013). Iklan yang Efektif sebagai Strategi Komunikasi Pemasaran. Jurnal Ekonomi Dan Kewirausahaan, 13(2), 116-129.

Moleong, L. J. (2017). Metodologi Penelitian Kualitatif (Edisi Revisi). In PT. Remaja Rosda Karya.

Norris, Christopher. 2003. Membongkar Teori Dekonstruksi Jacques Derrida (Terjemahan Inyiak Ridwan Muzir). Yogyakarta: Arruz Media.

Oktafiandi, I. (2018). Strategi Kreatif Iklan "Kisah Legenda Nusantara” dalam Menumbuhkan Brand Awareness Indoeskrim Nusantara. Jurnal Visi Komunikasi, 17(1), 1-11.

Permana, G. (2017). Visualisasi Seni sebagai Aspek Kreatif Periklanan. Jurnal Bahasa Rupa, 1(2), 108114.

Ratna, N. K. 2010. Teori, Metode, dan Teknik Penelitian Sastra. Denpasar: Pustaka Pelajar.

Ruslan, T. S. (2016). Transformasi Teks Cerita Rakyat ke dalam Bentuk Cerita Bergambar sebagai Model Pembelajaran Membaca Apresiatif. LITERA, 17(1), 389-401.

Setyawan, H. (2013). Membangun Film Animasi Cerita Rakyat Indonesia. Jurnal Komunikasi PROFETIK, 6(1), 31-42.

Siregar, M. (2019). Kritik terhadap Teori Dekonstruksi Derrida. Journal of Urban Sociology, Vol. 2 No. 1 , April 2019.

Suseno, S. (2019). Alih Wahana Hujan Bulan Juni. Jurnal Sastra Indonesia, 7(3), 212-220. https://doi.org/https://doi.org/10.15294/jsi.v7i3.29847

Syafrina, R. (2014). Analisis Dekonstruksi terhadap Tiga Dongeng Grimms Bersaudara: Rapunzel, Snow Drop, dan Ashputtel. Diglossia, Vol 6 No. 2, September 2014.

Vera, N. (2014). Semiotika dalam riset komunikasi. Ghalia Indonesia.

Yusa, I. M. (2014). Pengembangan Aplikasi Penyampaian Kearifan Lokal Melalui Cerita Rakyat Bali untuk Anak Sekolah Dasar Berbasis Mobile.Jurnal S@CIES, 5(1), 24-32. 